\title{
IMPLEMENTASI COLLABORATIVE LEARNING DALAM MENINGKATKAN PEMAHAMAN MAHASISWA PADA MATA KULIAH RISET OPERASI INFORMATIKA PROGRAM STUDI PENDIDIKAN TEKNOLOGI INFORMASI STKIP PGRI SITUBONDO
}

\author{
Dyan Yuliana ${ }^{1}$, Siti Seituni ${ }^{2}$, Sahwari $^{3}$, Ummy Heny $^{4}$ \\ $1,2,3,4$ STKIP PGRI Situbondo, Indonesia \\ Corresponding Email: pitikpitik23@gmail.com
}

Received: Nov 2, 2020

Revised: Nov 10, 2020

Accepted: Nov 12, 2020

\begin{abstract}
ABSTRAK
Proses pembelajaran di lembaga pendidikan khususnya perguruan tinggi merupakan suatu kegiatan interaktif antara mahasiswa dan dosen. Dosen tidak hanya menjadi pusat dari kegiatan proses pembelajaran, namun keterlibatan mahasiswa yang aktif dan penggunaan metode belajar yang sesuai juga penting. Masih kurangnya keaktifan mahasiswa dalam kegiatan diskusi maupun saat mengikuti kegiatan pembelajaran dipengaruhi oleh rendahnya perhatian mahasiswa dalam belajar, sehingga masih sering terlihat mahasiswa yang kurang konsentrasi dalam mengikuti perkuliahan. Agar dapat merangsang mahasiswa untuk terlibat aktif dalam kegiatan proses pembelajaran, dosen dituntut harus lebih kreatif dalam menyelenggarakan kegiatan pembelajaran, diantaranya dengan menguasai materi pembelajaran dan mampu menerapkan model \& metode pembelajaran yang sesuai dengan materi yang akan disampaikan. Penelitian ini ditujukan untuk mengetahui implementasi collaborative learning untuk meningkatkan pemahaman mahasiswa pada mata kuliah Riset Operasi Informatika. Metode penulisan yang digunakan dalam penelitian ini yaitu metode kualitatif yang mana data-datanya diperoleh dari hasil observasi dan wawancara yang bercorak deskriptif analitis atau analitis kritis, yaitu mengkaji gagasan primer mengenai ruang lingkup permasalahan yang dipercaya oleh gagasan sekunder yang relevan. Hasil dari penelitian ini dapat disimpulkan bahwa implementasi collaborative learning dapat meningkatkan pemahaman mahasiswa terhadap materi Riset Operasi Informatika, sehingga dapat digunakan dalam proses pembelajaran mata kuliah tersebut.
\end{abstract}

Kata kunci : Collaborative Learning, Pemahaman Mahasiswa, Riset Operasi Informatika.

\begin{abstract}
The learning process in educational institutions, especially universities, is an interactive activity between students and lecturers. Lecturers are not only the center of the learning process activities, but active student involvement and the use of appropriate learning methods are also important. The lack of student activeness in discussion activities and when participating in learning activities is influenced by the low attention of students in learning, so it is often seen that students are still less concentrated in attending lectures. In order to stimulate students to be actively involved in the learning process, lecturers are required to be more creative in carrying out learning activities, including by mastering learning materials and being able to apply learning models \& methods in accordance with the material to be delivered. This study aims to determine the implementation of collaborative learning to improve student understanding of the Informatics Operations Research course. The writing method used in this research is a qualitative method in which the data is obtained from the
\end{abstract}


results of observations and interviews with descriptive analytical or critical analytical characteristics, namely examining primary ideas about the scope of the problem which are believed by relevant secondary ideas. The results of this study can be concluded that the implementation of collaborative learning can improve students' understanding of the Informatics Operations Research material, so that it can be used in the learning process of these subjects.

Keywords: Collaborative Learning, Student Understanding, Informatics Operations Research.

\section{PENDAHULUAN}

Agar dapat merangsang mahasiswa untuk terlibat aktif dalam kegiatan proses pembelajaran, dosen dituntut harus lebih kreatif dalam menyelenggarakan kegiatan pembelajaran, diantaranya dengan menguasai materi pembelajaran dan mampu menerapkan model \& metode pembelajaran yang sesuai dengan materi yang akan disampaikan, sehingga dapat tercipta kondisi pembelajaran yang efektif dan tujuan pembelajaran yang telah ditetapkan dapat tercapai dengan baik.

Hal ini dapat mempengaruhi minat dan tingkat pemahaman mahasiswa terhadap materi yang dibahas. Dalam kegiatan pembelajaran komunikasi antara mahasiswa dan dosen harus sama-sama aktif dalam mentransfer ilmu pengetahuan, tidak hanya dari dosen tetapi juga antar mahasiswa

Berdasarkan hasil pengamatan selama perkuliahan Riset Operasi Informatika mahasiswa semester VI (enam) Program Studi Pendidikan Teknologi Informasi pada semester ganjil banyak ditemukan permasalahan yang dihadapi. Sebagian besar mahasiswa masih berbicara dengan teman di dekatnya saat kegiatan proses pembelajaran berlangsung. Pada saat dilakukan kegiatan diskusi hanya sebagian kecil saja yang aktif, sedangkan selebihnya hanya ikut-ikutan saja sebagai pelengkap serta masih banyak mahasiswa yang mengerjakan kegiatan sendiri di luar forum seperti bercanda.

Masih kurangnya keaktifan mahasiswa dalam kegiatan diskusi maupun saat mengikuti kegiatan pembelajaran dipengaruhi oleh rendahnya perhatian mahasiswa dalam belajar, sehingga masih sering terlihat mahasiswa yang kurang konsentrasi dalam mengikuti perkuliahan. Hal tersebut menyebabkan mahasiswa mengalami kesulitan dalam memahami materi yang disampaikan oleh dosen. Tingkat pemahaman terhadap materi kuliah masih rendah dan hanya beberapa mahasiswa saja yang paham, akan tetapi belum optimal. Untuk mengatasi semua permasalahan di atas dapat dilakukan dengan memberikan metode pembelajaran yang variatif yang sesuai dengan kondisi mahasiswa dan karakteristik pembelajaran agar mereka merasa senang untuk belajar dan dapat memecahkan masalah dengan sikap terbuka, kreatif, dan inovatif. Berdasarkan masalah diatas, peneliti tertarik 
melakukan penelitian dengan judul "Implementasi Collaborative Learning Untuk Meningkatkan Pemahaman Mahasiswa Pada Mata Kuliah Riset Operasi Informatika Program Studi Pendidikan Teknologi Informasi STKIP PGRI Situbondo".

Tujuan penelitian ini ialah untuk mengetahui bagaimana implementasi collaborative learning dalam meningkatkan pemahaman mahasiswa pada mata kuliah Riset Operasi Informatika Program Studi Pendidikan Teknologi Informasi STKIP PGRI Situbondo. Peneliti mengimplementasikan collaborative learning sebagai metode pembelajaran dalam mata kuliah Riset Operasi Informatika pada mahasiswa semester VI (enam) Program Studi Pendidikan Teknolologi Informasi di STKIP PGRI Situbondo.

\section{METODE PENELITIAN}

Penelitian ini dilaksanakan di STKIP PGRI Situbondo pada bulan Maret sampai dengan Agustus 2020. Metode penelitian yang digunakan dalam penelitian ini yaitu metode deskriptif dengan pendekatan kualitatif. Metode penelitian kualitatif yaitu penelitian yang bermaksud untuk memahami fenomena tentang apa yang dialami oleh subjek penelitian misalnya perilaku, persepsi, motivasi, tindakan, dan lain-lain (Lexy J. Moleong, 2013, p. 6).

Penelitian ini dilakukan di STKIP PGRI Situbondo pada mahasiswa semester VI Program Studi Pendidikan Teknologi Informasi. Data penelitian diperoleh melalui observasi, wawancara, dan dokumentasi. Penelitian ini dilakukan untuk mengukur implementasi collaborative learning dalam meningkatkan pemahaman mahasiswa pada mata kuliah Riset Operasi Informatika materi cara pembuatan model dalam riset operasi. Penelitian ini dilakukan selama bulan April 2020 dengan pertemuan tatap muka langsung selama 3 kali pertemuan.

Pertemuan pertama, mahasiswa diberikan tugas untuk menjelaskan cara-cara pembuatan model dalam riset operasi dari materi yang disampaikan oleh dosen dengan metode kolaborasi. Mahasiswa menyelesaikan tugas dengan cara mencari referensi di internet, bertanya pada temannya, dan mereka terlihat aktif dan bersemangat saat mengerjakan tugas yang diberikan oleh dosen.

Pertemuan kedua, dosen memeriksa hasil tugas mahasiswa dan memberikan koreksi pada jawaban yang kurang tepat. Beberapa kelompok sempat merasa tidak mampu menyelesaikannya tetapi dengan arahan dan kesabaran dosen, akhirnya semua anggota kelompok mampu menyelesaikan tugasnya dengan baik. Pada saat mengalami kesulitan, mahasiswa mulai berani dan tidak merasa malu untuk bertanya kepada temannya dan juga dosen. Dosen dengan telaten terus memantau aktivitas mahasiswa, sehingga kegiatan pembelajaran yang dilaksanakan tidak membuat mahasiswa cepat jenuh/bosan dikarenakan 
metode pembelajaran yang diterapkan oleh dosen membuat mereka merasa nyaman dan betah untuk belajar di kelas. Mahasiswa bersama dengan dosen mampu mengatur dan mengelola kelompok dalam skala kelas, sehingga sebagian besar mahasiswa aktif dalam kegiatan kelompok belajar serta saling membantu dan menjaga agar project yang dikerjakan sesuai dengan tujuan pembelajaran.

Dalam penelitian ini, peneliti mendeskripsikan dan menganalisis hal-hal yang berkaitan dengan implementasi collaborative learning untuk meningkatkan pemahaman mahasiswa pada mata kuliah Riset Operasi Informatika melalui pendekatan kualitatif dengan metode deskriptif. Data yang diperoleh berdasarkan hasil observasi, wawancara, serta dokumentasi.

Penelitian ini terdiri dari 2 variabel meliputi variabel independen (variabel bebas) yaitu model pembelajaran collaborative learning dan variabel dependen (variabel terikat) ialah pemahaman mahasiswa. Penelitian ini dilaksanakan untuk mengetahui implementasi variabel independen terhadap variabel dependen.

Untuk penetapan keabsahan data (trustworthiness) diperlukan teknik pemeriksaan. Pelaksanaan teknik pemeriksaan didasarkan pada kriteria tertentu. Ada kriteria yang digunakan, yaitu derajat kepercayaan (credibility) (Lexy J. Moleong, 2013, p. 324). Uji kredibilitas data atau kepercayaan terhadap data hasil penelitian kualitatif dilakukan dengan perpanjangan pengamatan, peningkatan ketekunan, dan triangulasi ((Sugiyono, 2013). Untuk memperoleh data yang akurat dan validitasnya dapat dipertanggungjawabkan, maka peneliti menggunakan teknik observasi, wawancara, dan dokumentasi. Untuk mengetahui implementasi collaborative learning pada mata kuliah Riset Operasi Informatika, maka teknik analisis deskriptif dilakukan dengan 2 tahap, yaitu organisasi data serta koding dan analisis.

\section{HASIL DAN PEMBAHASAN}

Dalam collaborative learning, kerjasama dalam kelompok sangat penting sehingga mengharuskan mahasiswa untuk berdiskusi, bermusyawarah, dan saling bertukar pendapat/ide. Dalam menyelesaikan project yang diberikan dosen, kegiatan diskusi, musyawarah, dan bertukar pendapat/ide sangat terlihat didalam kelas. Mahasiswa begitu antusias dalam kegiatan diskusi dan mereka mampu membuat kondisi kelas tetap kondusif hingga pembelajaran selesai.

Pembagian anggota kelompok dan nomor urut presentasi di depan kelas dilakukan sesuai dengan hasil kesepakatan bersama dengan seluruh mahasiswa. Hal ini menunjukkan bahwa dalam menentukan anggota kelompok nomor urut maju untuk presentasi tugas di depan kelas, dosen dan mahasiswa selalu bermusyawarah dan bertukar pendapat untuk menghindari kesenjangan antar anggota kelompok. 
Dalam menyelesaikan tugas (project), maka pemahaman materi, tugas, dan kewajiban harus benar-benar diperhatikan oleh seluruh mahasiswa begitu juga kerja sama dalam kelompok, sehingga antar mahasiswa yang satu dengan yang lainnya saling membantu temannya yang kurang memahami materi maupun mengalami kesulitan dalam menyelesaikan tugas. Pada saat mahasiswa menyelesaikan tugas yang diberikan dosen, mereka selalu mengutamakan musyawarah dan bertukar pendapat/ide, sehingga mampu untuk menghadapi masalah dan mampu mengemukakan pikiran atau ide-ide yang inovatif.

Kekurangan komunikasi antar mahasiswa selalu bisa diselesaikan dengan baik tanpa ada perselisihan, sehingga tidak menambah masalah yang dihadapi dan cenderung dapat menyelesaikannya. Terlihat ketika salah satu kelompok melakukan kesalahan dalam menyajikan materi, maka anggota kelompok lain langsung mengoreksi dan memberikan masukan sesuai dengan materi yang disampaikan. Masalah juga muncul saat beberapa mahasiswa dari kelompok lain berselisih pendapat, sehingga dosen harus menjadi penengah untuk ikut membantu menyelesaikannya dan mengarahkan mahasiswa mengenai jawaban yang benar dan tepat.

Pada sesi Wawancara ditunjukkan kepada beberapa mahasiswa semester VI Program Studi Pendidikan Teknologi Informasi di STKIP PGRI Situbondo untuk memperoleh informasi yang berkaitan dengan masalah yang dibahas dan diteliti. Wawancara dilakukan pada tanggal 20 Mei 2020 di rumah masing-masing informan/mahasiswa. Adapun kriteria penentuan informan yaitu memilih mahasiswa berdasarkan keaktifan dalam diskusi dan tanya jawab, keberanian mengemukakan pendapat, serta bertanggung jawab saat kegiatan pembelajaran berlangsung didalam maupun diluar kelas. Kemudian pada tanggal 27 Mei 2020, peneliti melakukan triangulasi dan mewawancarai kembali mahasiswa yang berbeda dengan sebelumnya namun dengan kriteria yang sama.

Hal ini dilakukan agar peneliti dapat memperoleh informasi yang lebih mendalam tentang masalah yang akan diteliti. Berikut ini biodata informan yang berasal dari 5 mahasiswa yang mengikuti mata kuliah Riset Operasi Informatika, diantaranya :

Tabel 1. Data Informan Mahasiswa

\begin{tabular}{|c|l|c|c|}
\hline No. & \multicolumn{1}{|c|}{ Nama Informan } & Status & Alamat \\
\hline 1. & Ahmad Bashori & Mahasiswa & Bungatan \\
\hline 2. & Septian Firmansah & Mahasiswa & Bungatan \\
\hline 3. & Siti Khotijah & Mahasiswa & Bungatan \\
\hline 4. & Ahmad Fathor Rozi Lutfi & Mahasiswa & Besuki \\
\hline 5. & Muhlishotun & Mahasiswa & Besuki \\
\hline
\end{tabular}


Dokumentasi yang dimaksud adalah foto kegiatan pembelajaran dengan metode collaborative learning dan dokumentasi lainnya berupa pelaksanaan wawancara serta datadata lainnya yang ada di STKIP PGRI Situbondo yang berkaitan dengan penelitian.

Sebelum melaksanakan penelitian, peneliti terlebih dahulu menyiapkan materi kuliah yang akan digunakan untuk kegiatan pembelajaran yaitu Rencana Pelaksanaan Pembelajaran (RPP) yang telah disiapkan sejak awal semester dan telah ditandatangani oleh salah satu perwakilan mahasiswa. Peneliti memilih RPP sebanyak 3 kali pertemuan untuk kegiatan penelitian ini, lalu merencanakan bagaimana pelaksanaan pembelajaran pada materi tersebut. Seluruh pertemuan pembelajaran dilakukan didalam kelas.

Sebelum memulai kegiatan pembelajaran, dosen mengucapkan salam terlebih dahulu kemudian meminta salah satu mahasiswa untuk memimpin do'a sebelum dimulainya pembelajaran. Setelah itu, dosen melihat kondisi didalam kelas yang belum kondusif terlihat dari masih banyaknya mahasiswa yang bercengkerama, bercanda, tidur, bermain game menggunakan handphone, dan belum fokus pada materi perkuliahan. Oleh karena itu, dosen melakukan ice breaking yang bertujuan untuk mengembalikan fokus dan perhatian mahasiswa, menghilangkan rasa kantuk, jenuh/bosan, dan kembali semangat mengikuti pembelajaran yang sedang berlangsung. Saat kondisi kelas mulai kondusif, dosen memberitahu materi perkuliahan yang akan disampaikan yaitu cara pembuatan model dalam riset operasi. Namun sebelum materi disampaikan, dosen mengulang kembali materi yang telah disampaikan pada pertemuan sebelumnya agar mahasiswa tidak melupakan materi yang telah diberikan. Lalu dosen menjelaskan kompetensi dan tujuan pembelajaran yang akan dicapai pada pertemuan ini.

Pada pertemuan berikutnya, dosen mempersiapkan kelas dan mengatur tempat duduk peserta didik menjadi 8 kelompok secara acak yaitu mengkolaborasikan mahasiswa dengan kemampuan tinggi, sedang, dan rendah. Kemudian dosen mengabsen mahasiswa dan menanyakan persiapan mereka untuk berdiskusi dan menyelesaikan tugas yang diberikan pada masing-masing kelompok. Setelah semuanya siap, lalu dosen memberikan pengarahan kepada semuakelompok agar mengikuti kegiatan diskusi kelompok dengan baik dan kondusif.

Pada pertemuan selanjutnya, dosen meminta mahasiswa untuk menyerahkan tugas dan hasil diskusi masing-masing kelompok lalu mempresentasikannya di depan kelas. Dosen dan mahasiswa lainnya mendengarkan dan menyimak dengan baik temannya yang sedang presentasi, kemudian pada sesi tanya jawab berlangsung, mahasiswa dari kelompok lainnya aktif berdiskusi, bertanya maupun mengemukakan pendapat/masukan. 
Setelah membacakan kompetensi dan tujuan, dosen menjelaskan tentang materi cara pembuatan model dalam riset operasi dengan metode ceramah, lalu memberikan pertanyaan kepada mahasiswa untuk dijawab dengan tujuan untuk mempertajam pengetahuan mahasiswa. Pada kegiatan disini banyak mahasiswa yang belum paham dengan materi cara pembuatan model dalam riset operasi, begitu juga dengan semangat belajar mahasiswa yang merasa jenuh mendengarkan penjelasan dosen, sampai pada saat dosen memberikan tugas diskusi, semangat belajar mahasiwa sedikit demi sedikit meningkat dan banyak dari mereka yang bertanya bahkan mereka mengambil materi tidak hanya dari modul mata kuliah yang diberikan oleh dosen, tetapi juga dari buku-buku yang mereka miliki, referensi dari internet, dan bertanya kepada dosen.

Pertemuan berikutnya, dosen membagi mahasiswa menjadi 8 kelompok yang terdiri dari 5 mahasiswa pada masing-masing kelompok. Kemudian dosen mengarahkan mahasiswa tentang cara diskusi dengan anggota kelompok, lalu dosen melihat jalannya kegiatan diskusi dan melihat hasil tugas yang diberikan kepada kelompok. Pada pertemuan ini, mahasiswa mulai semangat mendiskusikan materi masing-masing kelompok yang dibagikan oleh dosen. Pada saat kegiatan diskusi, banyak sekali pendapat anggota kelompok yang berseberangan. Pendapat-pendapat tersebut dikelola dengan baik dengan cara didiskusikan dan dimusyawarahkan kembali, sehingga diperoleh kesepakatan bersama berupa hasil diskusi final dan tidak lagi membuat mereka saling berbeda pendapat. Disaat mahasiswa berbeda pendapat, dosen hanya menjadi penengah yaitu saat situasi diskusi menjadi tidak kondusif dan dosen lebih banyak menyaksikan mahasiswa mengeluarkan pendapat dan mencatat segala aktivitas yang dilakukan mahasiswa terkait proses pembelajaran sebagai bahan penilaian.

Pertemuan selanjutnya, dosen meminta mahasiswa untuk mempresentasikan hasil diskusi masing-masing kelompok. Namun, sebelumnya dosen menghimbau kepada anggota kelompok yang belum mendapat tugas presentasi di depan kelas agar memperhatikan dan menyimak dengan baik dan seksama, lalu mereka mencatat kekurangan dan kelebihan penyajian materi (presentasi) oleh kelompok serta hal-hal yang belum dipahami dari materi yang dipresentasikan. Pada pertemuan ini, mahasiswa terlihat sangat antusias dikarenakan mereka mempresentasikan hasil diskusinya dan mahasiswa dari kelompok lainnya dapat aktif bertanya dan mengemukakan pendapat atau memberikan masukan. Dalam kondisi kelas yang seperti ini membuat dosen tidak banyak melakukan ceramah dengan memberikan materi dikarenakan mahasiswa sudah banyak belajar, namun dosen dan hanya memberikan penguatan serta motivasi belajar agar mahasiswa lebih semangat dan antusias dalam belajar.

Setelah dilakukan tanya jawab, dosen menyimpulkan materi yang telah dipelajari dan memberikan motivasi kepada mahasiswa untuk terus membaca buku dan belajar serta terus 
berusaha saat berada luar kelas. Kemudian dosen meminta salah satu mahasiswa untuk memimpin do'a dan mengucapkan salam.

Dengan adanya implementasi collaborative learnig dalam proses mupembelajaran membuat mahasiswa lebih mudah memahami materi pelajaran karena mereka dapat berdiskusi dengan anggota kelompoknya jika ada materi yang belum dipahami. Kegiatan diskusi dan tanya jawab di kelas juga berperan penting dalam membantu guru menyampaikan materi pelajaran serta meningkatkan keaktifan dan rasa percaya diri mahasiswa.

Pembelajaran harus didesain/dirancang secara praktis, sistematis, dan berkesinambungan. Sedangkan mahasiswa merupakan pihak yang merespon dan menikmati kondisi belajar yang diciptakan oleh dosen. Mahasiswa memiliki potensi, minat, dan kemampuan yang harus dikembangkan agar semakin optimal. Oleh karena itu, proses pembelajaran seharusnya dapat menumbuhkembangkan ketiga hal tersebut sebagai langkah optimalisasi potensi diri, sehingga akan dicapai kualitas yang ideal.

Dalam proses pembelajaran dengan metode collaborative learning dapat mempermudah pelaksanaan pembelajaran karena mahasiswa tidak hanya mendengarkan penjelasan dari dosen tetapi juga mempraktikkan sendiri apa yang mereka lakukan, sehingga lebih mudah memahami materi yang sedang dipelajari. Dari penjelasan diatas, diketahui bahwa implementasi collaborative learning sebagai metode pembelajaran merupakan suatu desain pembelajaran yang mengeluarkan potensi lain dari mahasiswa dan memudahkan mahasiswa dalam memahami materi pembelajaran. Hal ini sesuai dengan hasil wawancara yang peneliti temukan bahwa mahasiswa dapat memperoleh berbagai pengetahuan dan pengalaman dengan belajar secara kolaboratif/berkelompok.

Proses pembelajaran dengan menggunakan metode collaborative learning dalam mengerjakan tugas itu lebih baik dibandingkan dengan mengerjakan sendiri, dikarenakan mahasiswa lebih bersemangat belajar jika dikerjakan bersama-sama. "senang, karena bisa saling bertukar pendapat". Begitulah pernyataan mahasiswa setelah mengerjakan tugas dengan kelompok. Pernyataan diatas menunjukkan bahwa mahasiswa lebih senang belajar dalam kelompok dibandingkan belajar dengan memahami sendiri, sebab belajar dengan metode collaborative learning tidak hanya meningkatkan pemahaman mahasiswa tetapi juga timbulnya rasa solidaritas yang sama dalam memahami materi pelajaran, sehingga tidak ada kata mahasiswa yang satu lebih paham dari mahasiswa yang lainnya. Dibandingkan dengan belajar sendiri, belajar dengan kelompok lebih memudahkan mahasiswa dalam memahami materi pelajaran, selain itu mereka juga lebih aktif dalam kegiatan pembelajaran seperti diskusi, bertanya, berkomunikasi, bertanggung jawab, dan mengemukakan pendapat/ide. 
Dalam hal memahami materi, mahasiswa juga tidak terlalu banyak mengalami kesulitan dikarenakan mahasiswa dapat bertanya kepada siapapun, termasuk kepada temannya yang sudah paham. "sangat memudahkan" dan "mencari referensi dan berkonsultasi" . Pernyataan tersebut dikemukakan oleh mahasiswa saat ditanya tentang kemudahan memahami materi melalui metode collaborative learning. Pernyataan diatas menunjukkan kemudahan mahasiswa memahami materi dengan implementasi collaborative learning. Hal ini dikarenakan mahasiswa aktif dalam mencari pengetahuan tentang suatu materi yang belum mereka pahami, sehingga bertanya dan mengeluarkan pendapat memudahkan mereka untuk mendapatkan pengetahuan yang mereka butuhkan. Kesulitan yang mereka hadapi dapat dengan mudah mereka diselesaikan dikarenakan mereka dapat bertanya kepada sesama temannya dan menyelesaikan setiap permasalahan yang ada secara bersama-sama. Musyawarah merupakan contoh kecil yang mereka lakukan saat terjadi kesalahpahaman antar mahasiswa. Melalui musyawarah, mereka bisa mempertanggung jawabkan pertanyaan, jawaban, ide-ide atau pendapat yang mereka pikirkan.

Strategi pembelajaran dengan implementasi collaborative learning membuat semangat belajar mahasiswa lebih meningkat dibandingkan dengan strategi pembelajaran yang lainnya. Menurut pendapat mahasiswa, belajar dengan metode collaborative learning hal yang sangat baik dan menarik "rasa solidaritas dan sangat membangun semangat belajar" dan "mampu membangunkan semangat belajar”. Begitulah kata mahasiswa ketika diwawancarai mengenai kesan yang mereka peroleh setelah melaksanakan pembelajaran dengan collaborative learning. Hal ini dikarenakan dosen menerapkan strategi dan metode pembelajaran yang tidak membosankan dan belum pernah digunakan sebelumnya dalam proses pembelajaran, sehingga meningkatkan motivasi belajar mahasiswa dan lebih mudah memahami materi pembelajaran.

Metode pembelajaran yang tidak sesuai dengan kondisi mahasiswa dan materi yang hendak disampaikan membuat mahasiswa merasa lebih cepat jenuh/bosan dan tidak semangat dalam memahami materi. Hal ini terjadi karena tidak adanya motivasi dalam diri mereka dan hal ini membuat mereka lebih cepat melupakan materi pembelajaran. "metode yang sangat bagus karena kita bisa saling bertukar ide". Kata salah satu mahasiswa saat ditanya tentang belajar dengan metode collaborative learning, hal ini membuktikan bahwa belajar dengan metode pembelajaran yang tepat akan membuat materi pelajaran lebih mudah untuk dipahami karena antar mahasiswa dengan mahasiswa dan juga dosen dapat saling bertukar ide/pendapat.

Pernyataan diatas membuat antusiasme dalam belajar meningkat. Dengan meningkatnya antusiasme belajar mahasiswa, maka kegiatan belajar menjadi lebih mudah dan tentunya 
banyak pengetahuan baru yang diperoleh mahasiswa. "cukup lumayan sebagai penambahan wawasan dan materi" dan "mampu membangunkan semangat belajar". Begitulah kata mahasiswa ketika diwawancarai hal yang diperoleh dan perasaan mereka saat melaksanakan proses pembelajaran dengan metode collaborative learning. Pernyataan diatas menunjukkan bahwa apa yang diperleh mahasiswa tidak hanya sebatas materi pelajaran saja, tetapi juga wawasan, pengalaman, dan semangat yang tinggi untuk belajar.

Disamping meningkatkan antusiasme dan pengalaman dalam belajar, collaborative learning merupakan salah satu metode pembelajaran membuat mahasisswa merasakan mudahnya dalam menuntut ilmu serta salah satu cara yang bisa membuat peserta didik tidak jenuh dengan pendidikan "Iya mudah, asal saya pelajari terlebih dahulu". Hal ini membuktikan bahwa belajar dengan metode collaborative learning memudahkan mahasiswa memahami materi pelajaran.

Berdasarkan pembahasan diatas, ditemukan bahwa metode pembelajaran merupakan salah satu unsur yang sangat penting dalam kegiatan pembelajaran. Hal ini disebabkan karena pemilihan metode pembelajaran yang tepat sangat membantu dosen dalam memberikan pengajaran secara optimal, efektif, dan efisien. Dengan adanya metode dan strategi pembelajaran yang tepat dan sesuai dengan kondisi mahasiswa dan materi yang akan disampaikan, mahasiswa dapat belajar dengan mudah, merasa senang dan bersemangat, serta tidak cepat jenuh dalam mengikuti proses pembelajaran dari awal hingga selesai. Biasanya mahasiswa dapat menyerap materi pembelajaran dengan mudah jika proses pembelajaran yang dilaksanakan menarik, menyenangkan, dan membangunkan semangat belajar. Peran seorang dosen sangat besar dalam melaksanakan pembelajaran yang yang tepat, bukan hanya pembelajaran yang berbasis konvensional. Seorang dosen harus memahami tingkat kemampuan dan tipe belajar mahasiswa, artinya dosen perlu menyesuaikan gaya mengajarnya terhadap gaya belajar mahasiswanya. tepat dan efisien bagi mahasiswa dengan pemilihan metode pembelajaran Proses pembelajaran yang baik ditunjang dari suasana pembelajaran yang kondusif serta hubungan komunikasi antara dosen dan mahasiswa yang berjalan dengan baik.

\section{KESIMPULAN}

Hasil penelitian yang telah dilakukan dapat disimpulkan bahwa implementasi collaborative learning bisa dan sesuai diterapkan dalam mata kuliah Riset Operasi Informatika. Hal ini dapat dilihat dari hasil wawancara, observasi, dan dokumentasi yang dilakukan peneliti kepada mahasiswa, diantaranya :

1. Model collaborative learning meningkatkan pemahaman mahasiswa terhadap materi pembelajaran. 
2. Belajar dengan model collaborative learning membuat proses pembelajaran menjadi lebih mudah dan menyenangkan.

3. Kegiatan kolaborasi belajar dalam kelompok menjadikan mahasiswa lebih aktif dan semangat dalam mengikuti proses perkuliahan dari awal hingga akhir pembelajaran.

Dari uraian diatas, maka implementasi collaborative learning dapat digunakan dalam proses pembelajaran mata kuliah Riset Operasi Informatika bagi mahasiswa semester VI Program Studi Pendidikan Teknologi Informasi STKIP PGRI Situbondo.

\section{DAFTAR RUJUKAN}

Akbar, M.N. Skripsi : Implementasi Pendekatan Collaborative Learning Melalui Pembuatan Video Mata Pelajaran Pendidikan Agama Islam. Retrieved from:http://repository.uinjkt.ac.id/dspace/bitstream/123456789/41494/1/MUHAMMAD \%20NURUDIN\%20AKBAR-FITK.pdf. 30 Maret 2020.

Amalia, N.R. Minggu, 26 Maret 2017. Riset Operasi. http://nadyarizkiamalia.blogspot.com/2017/03/riset-operasi.html. 29 Maret 2020.

Barkley, Elizabeth E., dkk. 2014. Collaborative Learning Techniques (Teknik-teknik Pembelajaran Kolaboratif), cetakan ke-3. Bandung : Nusa Media.

Departemen Pendidikan Nasional. 2014. Kamus Besar Bahasa Indonesia. Jakarta: Gramedia. Fatoni, Y.A. Skripsi : Upaya Meningkatkan Pemahaman Siswa Dalam Pembelajaran Matematika Materi Bangun Datar Dengan Metode Demonstrasi Pada Siswa Kelas II Semester II MI Ma'arif Tanjunganom Kecamatan Salaman Kabupaten Magelang. Retrieved from : $\quad$ http://digilib.uinsuka.ac.id/14006/1/BAB\%20I\%2C\%20IV\%2C\%20DAFTAR\%20PUSTAKApdf. 31 Maret 2020.

Handayani, B.D. (2011, June). Efektivitas Pembelajaran Aktif Melalui Penerapan Model Pembelajaran Kolaboratif (Collaborative Learning) Untuk Meningkatkan Prestasi Belajar Akuntansi Sektor Publik Pokok Bahasan Akuntansi Satuan Kerja Pengelola Keuangan Daerah (SKPKD). Jurnal Pendidikan Ekonomi Dinamika Pendidikan, 6(1), 62-77.

Hasibuan, R.W. Kamis, 04 Maret 2010. Fungsi Riset Operasi. http://rizkyf5ers.blogspot.com/2010/03/fungsi-riset-operasi.html. 29 Maret 2020.

Inah, E.N. \& Pertiwi, U.A. (2017, January-June). Penerapan Collaborative Learning Melalui Permainan Mencari Gambar Untuk Meningkatkan Hasil Belajar IPA Kelas V Di SDN Tabanggele Kecamatan Anggalomoare Kabupaten Konawe. Jurnal Al-Ta'dib, 10(1), 19-36. 
Iskandar. 2013. Metodologi Penelitian Pendidikan dan Sosial. Jakarta : Referensi.

Lexy J. Moleong. 2013. Penelitian Kualitatif (edisi revisi). Bandung : PT. Remaja Rosdakarya.

Mahmud. 2011. Metode Penelitian Pendidikan. Bandung : CV Pustaka Setia.

Mahpur, Mohammad. Memantapkan Analisis Data Kualitatif Melalui Tahapan Koding. http://repository.uin-malang.ac.id/800/2/koding.pdf. 30 Maret 2020.

Poerwandari, E.K. 1998. Pendekatan Kualitaif dalam Penelitian Psikologi, Jakarta : LPSP3.

Sarosa, S. 2012. Penelitian Kualitatif Dasar-dasar. Jakarta: Indeks.

Sudarman. (2018, March). Jurnal Pendidikan Inovatif : Penerapan Metode Collaborative Learning untuk Meningkatkan Pemahaman Materi Mata Kuliah Metodologi Penelitian. Retrieved from https://www.researchgate.net/publication/323510688_penerapan_metode_collaborative _learning_untuk_meningkatkan_pemahaman_materi_kuliah_metodologi_penelitian. 30 Maret 2020.

Sugiyono. 2013. Metode Penelitian Kuantitatif, Kualitatif, dan R\&D. Bandung : Alfabeta. Sugiyono. 2014. Memahami Penelitian Kualitatif. Bandung : Alfabeta.

Sukmadinata, N.S. 2011. Metode Penelitian Pendidikan. Bandung : PT. Remaja Rosdakarya.

Sulistyawati, N. \& Zuchdi, D. (2016, March). Implementasi Teknik Pembelajaran Kolaboratif Dengan Variasi Media Untuk Peningkatan Hasil Belajar Di SMPN 2 Kalijambe. Jurnal Pendidikan IPS, 3(1), 50-61.

Sulystyowati, N.W. (2016, October). Implementasi Small Group Discussion dan Collaborative Learning Untuk Meningkatkan Prestasi Belajar Mahasiswa Program Studi Pendidikan Akuntansi IKIP PGRI Madiun. Jurnal Akuntansi dan Pendidikan, 5(2), 173-190. 